\title{
Adverse Drug Event Reporting System
}

National Cancer Institute

\section{Source}

National Cancer Institute. Adverse Drug Event Reporting System. NCI Thesaurus. Code C17443.

A Web application developed for the electronic submission of Expedited Reports to the $\mathrm{NCl}$ for serious and/or unexpected Adverse Events, deaths, and other events defined in the $\mathrm{NCl}$ Guidelines: Adverse Event Reporting Requirements for $\mathrm{NCl}$ Investigational Agents 